\title{
Keluarga Yang Misioner
}

\author{
Fransiskus Irwan Widjaja* \\ Irwanwidjaja.fiw@gmail.com \\ Paper Presented for National Seminar STT Real Batam 2018
}

\begin{abstract}
:
Tujuan tulisan ini adalah untuk menjelaskan dan membahas deskriptif eksegese. Subyek yang jelaskan di ambil dari 1 Samuel 30: 3, Daud seoarang kepala keluarga yang juga seorang pemimpin, orang yang di pakai Tuhan dengan luar biasa, yang membawa dampak buat kota, bisa mengalami kekalahan telak bukan karena beliau gagal berperang karena istri dan anak anak (keluarga) menjadi tawanan bahkan kota tempat tinggalnya terbakar.

Keluarga adalah simbol kehidupan. keluarga bergerak sejak lahir, kedewasaan, dan kematian, adalah penting mempertahankan iman percaya. Perubahan sosial dan budaya terjadi di daerah perkotaan dan pedesaan, begitu juga keluarga. Keluarga juga menentukan kota di mana kita tinggal. Kesejahteraan kota tergantung pada keluarga orang percaya yang tinggal di kota itu. Penting nya pemuridan dalam keluarga, bagaimana iman orang tua di turunkan kepada anak anak nya. Penulis percaya bahwa perspektif teoretis tentang keluarga adalah penting.
\end{abstract}

\section{Samuel 30: 3}

Ketika Daud dan orang orangnya sampai ke kota itu, tampaklah kota itu terbakar habis, dan isteri mereka serta anak mereka yang laki laki dan perempuan telah di tawan.

\section{Pendahuluan}

Daud, kota dan keluarga adalah tiga pokok bahasan yang tidak bisa terlepas dalam teologi keluarga. Daud seorang hamba Tuhan, pemimpin, bukan hanya memimpin rakyat tetapi Daud juga memimpin kota dan Keluarga. Keberadaan seorang pemimpin, hamba Tuhan akan membawa dampak kepada kota di mana dia berada atau tinggal, tetapi juga Keluarga.

Kesibukan Daud dalam memikirkan strategi menduduki kota dan menguasai wilayah, kesibukannya membuat satu kesalahan fatal, ketika dia sampai di kota nya, kota itu sudah terbakar, istri bahkan anak anak nya baik laki laki dan perempuan sudah menjadi tawanan. Pesan moral yang di dapat mengingatkan gereja Tuhan, hamba Tuhan, siapa pun kita yang terlalu sibuk mengembangkan pelayanan, bisnis, pekerjaan, sibuk dengan segala strategi, sehingga seringkali kita mengabaikan keluarga. Berhasil dalam karier, tetapi kita kehilangan kota (tidak pernah di perhatikan, di doakan), yang sudah di 
kuasai dengan segala macam kejahatan bahkan membawa dampak bagi generasi atau keluarga kita. Istri dan anak telah menjadi tawanan. Tiga komponen penting dalam pembahasan kali ini:

\section{Daud}

Daud sebagai suatu studi kasus seorang ayah atau bapak dari pemimpin keluarga sampai pemimpin suatu bangsa. Potret karakter sebagai bapa dan raja, Daud selalu menarik untuk di teliti dan pria paling menarik di Alkitab. Alkitab menjelaskan pandangan yang benar-benar transparan tentang kehidupan Daud. Daud adalah seorang gembala, pemburu, prajurit, jenderal, raja, penyair, juara, penjahat, wanita pria, musisi, nabi, pemimpin pujian, pezina, pembunuh, saudara, suami, putra, orang tua, pemimpin, pahlawan, pembangun, leluhur Yesus Kristus, manusia yang menurut hati Allah sendiri. ${ }^{1}$ Alkitab referensi The Thompson Chai $^{2}$, "Tidak ada karakter Alkitab yang sepenuhnya menggambarkan jangkauan moral dari sifat manusia".

\section{Samuel berbicara tentang Tuhan yang memberi tahu Samuel untuk} berbicara dengan Isai, ayah Daud. Samuel bertemu Eliab, putra sulung Isai, dan sangat terkesan dengan cara Eliab menghadirkan dirinya. Tapi Tuhan berkata kepada Samuel: "Jangan menganggap penampilannya atau tinggi badannya, karena aku telah menolaknya. TUHAN tidak melihat hal-hal yang dilihat manusia. Manusia melihat penampilan luar, tetapi Tuhan melihat hati. "1 Sam 16: 7 Tidak ada yang di lirik Tuhan dari enam (6) putra Isai lainnya. Daud yang hampir dilupakan dan pasti tidak ditanggapi dengan sangat serius, tapi Samuel memilih Daud, yang termuda, bayi dari keluarga, sibuk bekerja di

\footnotetext{
${ }^{1}$ Kis 13:22a, Aku telah mendapat Daud binlsai, seorang yang berkenan di hati-Ku dan yang melakukan segala kehendak-Ku

2 Thompson Chain Referensi: Dr. Thompson percaya bahwa Alkitab harus disajikan dengan cara yang sederhana, tetapi ilmiah. Dia melihat kebutuhan akan Alkitab referensi yang terorganisir dengan baik yang akan berguna bagi orang awam maupun seorang pendeta. Pada tahun 1890, Dr. Thompson memulai pekerjaan yang akan ia teruskan selama sisa hidupnya. Dia menyelesaikan "saran pikiran" di seberang ayat-ayat di seluruh Alkitab. Ini adalah apa yang menjadi "mata rantai" yang merupakan jantung dari sistem Thompson. Beberapa pria di gereja Dr. Thompson melihat Alkitabnya dan memberi tahu dia bahwa ini akan sangat membantu mereka dalam pelajaran Alkitab juga. Mereka mendorong Dr. Thompson untuk meminta Alkitabnya, dengan referensi-referensi marjinal, diterbitkan sehingga semua orang dapat menikmati berkat dari alat belajar yang membantu ini. Kirkbride Bible Company. Di unduh tgl 10-08-2018
} 
lapangan, mengurus beberapa domba. Jadi dalam potret Daud, pekerja keras yang bertanggung jawab yang sibuk dengan tugasnya di tangan, rendah hati dan diangkat menjadi raja berdaulat di masa depan dari umat Tuhan. Daud yang di sebut 974 kali dalam Alkitab, Daud yang sukses merupakan juga Daud yang gagal dalam berumah tangga. Daud yang mengandalkan Tuhan, adalah daud yang kalah dalam rumah tangga, tetapi daud pada akhir hayat nya mati dalam kemuliaan.

1 tawarikh 29:28 Kemudian matilah ia pada waktu telah putih rambutnya, lanjut umurnya, penuh kekayaan dan kemuliaan, kemudian naik rajalah Salomo, anaknya, menggantikan dia

Alkitab mencatat sebagai orang yang mati di usia lanjut, putih rambutnya, penuh dengan kekayaan dan kemuliaan. Daud yang di tulis dalam Kisah Rasul 13:22, sebagai orang yang berkenan di Hadapan Tuhan, karena Daud melakukan kehendak Bapa pada jaman nya, Kis 13:36

Sebab Daud melakukan kehendak Allah pada zamannya, lalu ia mangkat dan dibaringkan di samping nenek moyangnya, dan ia memang diserahkan kepada kebinasaan.

Kehendak Bapa; Daud berhasil menurunkan imannya kepada generasinya.

\section{Tawarikh 29:8}

Dan engkau, anakku Salomo, kenallah Allahnya ayahmu dan beribadahlah kepada-Nya dengan tulus ikhlas dan dengan rela hati, sebab TUHAN menyelidiki segala hati dan mengerti segala niat dan cita-cita. Jika engkau mencari Dia, maka la berkenan ditemui olehmu, tetapi jika engkau meninggalkan Dia maka la akan membuang engkau untuk selamanya

\section{Kota}

Kota menurut Kamus Merriam webster ${ }^{3}$ : tempat di mana orang tinggal lebih besar atau lebih penting daripada kota; daerah dimana banyak orang tinggal dan bekerja. "Kamus" di Indonesia mendefinisikan kota sebagai tempat kompleks besar, penuh dengan bangunan dan daerah berpenduduk padat; Dapat mencakup beberapa distrik administratif independen atau pusat kota atau distrik administratif yang didirikan berdasarkan piagam negara bagian atau orang-orang yang tinggal di kotamadya padat penduduk yang luas.

\footnotetext{
${ }^{3}$ William Webster Dictionary meaning of City, ttps://www.merriam-webster.com/dictionary/city di unduh, July 2015 


\section{A. Kota dalam Terminologi Misi}

Kisah Para Rasul 1: 8 Tetapi kamu akan mendapat kuasa, jika Roh Kudus turun ke atas kamu dan kamu akan menjadi saksi-Ku di Yerusalem dan di seluruh Yudea dan Samaria dan sampai ke ujung bumi. Menurut ayat ini, bersaksi dimulai dari kota Yerusalem. Kota pertama yang ditulis oleh Lukas sebagai titik awal untuk mencapai bagian lain.

Seorang profesor Misi Roger S. Greenway mengatakan "Kota-kota adalah konsentrasi orang-orang yang tinggal berdekatan dan berinteraksi satu sama lain dalam bentuk korporasi dan pemerintahan. Kota sering digunakan untuk menunjukkan daerah perkotaan atau metropolitan "4

Karena itu, kota ini merupakan citra alkitabiah yang penting. Memahami penekanan alkitabiah tentang kota adalah hal penting. Yang paling sering disebut untuk kata kota dalam Perjanjian Lama adalah kata 'eer' yang berasal dari kata yang berarti dalam bahasa Ibrani 'tinggal' (sojourn/dwell). Telah dicatat dalam referensi kota-kota di Alkitab sebanyak 1200 referensi kota dan 119 kota-kota yang diberi nama. Beberapa tokoh Alkitab terkemuka dibangun, diperintah dan tinggal di kota. kota di bangun untuk tempat perlindungan, sebuah pemikiran yang selaras dengan tujuan membangun kota-kota Alkitab

Kain adalah pembangun pertama kota sesuai dengan Alkitab (Kej 4:17). Kemudian Nimrod pemburu besar membangun kota-kota (Kejadian 10: 8-10). Pembangun kota ini menunjukkan domain mereka dan menunjukkan pernyataan diri. Jika kota Kain berbicara tentang aman (safty) dan keamanan (security), kota-kota Nimrod mewakili dominasi. Keduanya melambangkan prestasi manusia dan penegasan diri. Seringkali orang kota bangga menggambarkan betapa amannya kota mereka. Kota menunjukkan penegasan, kebanggaan dan pencarian diri dari Tuhan ${ }^{5}$.

Kata Perjanjian Baru untuk kota adalah 'polis' yang tercatat sekitar 160 kali, terutama di Lukas dan Kisah Para Rasul. Dalam Perjanjian Baru konsep kota dikaitkan dengan populasi kepadatan yang tertutup oleh dinding yang melindungi. Era Perjanjian Baru adalah era perkotaan, terutama ketika

\footnotetext{
${ }^{4}$ Paul G. Heibert. Cultural Anthropology. 1997, hal. 269

${ }^{5}$ Manokaran JN 2005 : Christ and Cities: Transformation of Urban Centres, hal 5

4 Teologi Keluarga: Keluarga yang Misionair
} 
menyangkut kehidupan dan pelayanan rasul Paulus. Kota-kota terus mendominasi dunia Perjanjian Baru. Kisah Perjanjian Baru dengan mengagumkan menunjukkan penggunaan kota-kota untuk penetrasi Injil. ${ }^{6}$

\section{B. Panggilan Pemimpin Terhadap Kota}

Para pemimpin perkotaan berikut telah dipilih untuk memeriksa bagaimana memperluas pengaruh mereka terhadap laki-laki kota mereka dan memberi kontribusi pada pertumbuhan masyarakat. Abraham, Yusuf, Musa, Nehemia, Ester, Daniel, Yunus, Paulus, dan Lydia. Pemimpin perkotaan ini adalah pria dan wanita dengan kualitas kepemimpinan tinggi dan orang-orang yang sangat berpengaruh pada masanya.

\section{Penghakiman Tuhan atas Kota}

Tuhan mencintai kota, Kota adalah simbol keselamatan dan perlindungan Allah. Tetapi ketika kota-kota yang ditahbiskan menentang rencana dan tujuannya, dan melakukan dosa dan menjadi merugikan misinya dan akan mempengaruhi generasi yang akan datang, Dia menghancurkannya atau DIA menginjinkan kota itu untuk di duduki musuh.

Beberapa kota terpilih yang berada di bawah penghakiman Allah;

\section{a. Babel}

Kej 11:9 Itulah sebabnya sampai sekarang nama kota itu disebut Babel, karena di situlah dikacaubalaukan TUHAN bahasa seluruh bumi dan dari situlah mereka diserakkan TUHAN ke seluruh bumi.

b. Sodom dan Gomorah

Kejadian 19:24-30

Kemudian TUHAN menurunkan hujan belerang dan api atas Sodom dan Gomora, berasal dari TUHAN, dari langit; dan ditunggangbalikkan-Nyalah kota-kota itu dan Lembah Yordan dan semua penduduk kota-kota serta tumbuh-tumbuhan di tanah.

c. Yerikho

\footnotetext{
${ }^{6}$ Atul Y. Aghamkar, 2000, Insights Into Openness,: Encouraging Urban Mission, hal 4
} 
Yosua 6: 21

Mereka menumpas dengan mata pedang segala sesuatu yang di dalam kota itu, baik laki-laki maupun perempuan, baik tua maupun muda, sampai kepada lembu, domba dan keledai

d. Yerusalem

Yesaya 1:7 Negerimu menjadi sunyi sepi, kota-kotamu habis terbakar; di depan matamu orang-orang asing memakan hasil dari tanahmu. Sunyi sepi negeri itu seolah-olah ditunggangbalikkan orang asing.

\section{Kota kota Perjanjian Baru}

Paulus adalah Rasul perkotaan yang menginjili penduduk kota dan menanam gereja di beberapa kota di Kekaisaran Romawi. Paulus hampir menyentuh semua kota provinsi terkemuka Kekaisaran Romawi dengan Injil.

Paulus mengangkat, merekrut dan melatih para pemimpin kota yang dinamis seperti Timotius, Titus, Silas, Lukas, Akwila dan Pricilla dan Apolos dan menempatkan mereka di pelayanan kota.

Sebagian besar surat Paulus ditulis ke gereja-gereja kota sebagai petunjuk tentang bagaimana gereja dapat secara efektif menjalankan sebuah pelayanan di kota-kota. ${ }^{7}$

Paulus memberi contoh beberapa model dan latar belakang dalam menjangkau kota,

- Kota Pelabuhan (Troas, Tarsus, Antiokia dan Tesalonika) Paulus konsentrasi pada kota-kota besar, terutama pelabuhanpelabuhan utama.

- Roma : Kota Politik

Selama masa Paulus, Roma adalah ibukota kerajaan politik yang pada abad pertama Masehi diperluas dari Samudra Atlantik ke Teluk Persia dan dari Afrika Utara sampai ke Inggris dan Eropa utara. $^{8}$. Roma adalah pusat strategis penyebaran Injil.

- Athena: Kota Kebudayaan

\footnotetext{
7 Robert C. Linthicum, 1991. Kota Allah Kota Setan.1991. hal 22

${ }^{8}$ David C Cook, Bible Lesson Commentary 2013-2014, The Essential study for today disciple 6 Teologi Keluarga: Keluarga yang Misionair
} 
Athena adalah kota dan pusat filsafat yang terkenal. Keempat sekolah bersejarah yang terkenal telah didirikan dan berkembang di sini. ${ }^{9}$ Akademi Plato, Lyceum of Aristoteles, Serambi Zeno, dan Taman Epicurus. ${ }^{10}$ "Kunjungan Paulus ke Athena adalah bagian dari apa yang umumnya disebut sebagai "perjalanan misionaris kedua" Paulus.

- Filipi:Kota Kunci ke Makedonia

Filipi adalah kota besar orang Makedonia. Orang Makedonia kemudian menjadi tempat berpijak bagi Paulus dan membawa Injil lebih jauh ke Eropa.

- Korintus: Kota Kunci Acaia,

Korintus adalah kota Romawi yang strategis terletak di jalur darat utama antara Timur dan Barat dan merupakan persimpangan jalan beberapa rute laut. Paulus memulai pelayanannya di Korintus pada perjalanan misionaris keduanya di bawah banyak oposisi (Kis. 18: 6-17). Korintus adalah pusat bergengsi dimana Injil dapat menyebar ke daerah sekitarnya.

\section{- Efesus : Kota Kunci ke Asia Kecil}

Efesus juga merupakan ibukota provinsi Asia dan kota terkemuka Asia Kecil, di mana gereja berkembang dengan pesat. Paulus menghabiskan banyak waktu di Asia Kecil. Sebagai kota terdepan di Asia, dan kota utama di wilayah Asia Kecil yang lebih luas, Efesus jelas memiliki tempat yang signifikan dalam perkemabnagn agama Kristen di awal. Menurut Von Harnack, ${ }^{11}$ Efesus sebenarnya ditakdirkan menjadi markas besar iman, ini adalah ibu kota ketiga setelah Yerusalem dan Antiokhia. Beasly Murray ${ }^{12}$ mencatat bahwa: "gereja di Efesus adalah yang paling penting dalam Asia kecil dan mungkin gereja paling berpengaruh di dunia pada akhir abad pertama $A D_{-}$

Kota merupakan tanggung jawab bersama. Tuhan Memberikan Kunci yang

\footnotetext{
9 ibid

10 ibid

11 Von Harnack 1908, The Mission and Expansion of Christianity in The First Three Centuries, Vol 2. hal. 76

${ }^{12}$ Beasly Murray 1962, Tour the Force seperti di kutip dalam buku Paul, Artemis, and the Jews in Ephesus, Volume 80 
benar dan strategi kepada pemimpin (gereja) untuk menduduki dan menguasai kota dengan Pendekatan yang Tepat bagi gereja untuk menaklukkan kota. Tapi kadang-kadang Komunitas religius seperti orangorang Farisi di jaman dulu yang mengambil kunci pengetahuan (Lukas 11:52), tetapi mereka sendiri tidak masuk dan bahkan menghalangi orang-orang yang mungkin akan masuk. Kota-kota telah diberikan kepada kita oleh Karya Kristus di kayu salib dan janji di dalam Firman Tuhan. Kita memiliki pintu yang terbuka untuk kita masuk:

"Sebab di sini banyak kesempatan bagiku untuk mengerjakan pekerjaan yang besar dan penting, sekalipun ada banyak penentang, dalam bahasa Inggris di katakana pintu kesempatan yang besar di bukakan (For a great and effective door has opened to me, and there are many adversaries (1 Kor. 16:9).

Integritas dan nasib kota sering disebutkan di seluruh Alkitab. Menurut Frank Damazio ${ }^{13}$ : Setiap kota memiliki kepribadian kota dan takdir kota yang unik, begitu juga tujuh kota di provinsi Romawi di Asia yang dialamatkan dalam Wahyu. Gereja di kota Tiatira, misalnya, diberi peringatan tentang toleransi terhadap pengajaran tidak bermoral: (Wahyu 2: 19-20; lihat juga Wahyu 2-3).

Setiap kota memiliki tangisan tersendiri yang naik ke surga - Tuhan mendengar teriakan itu. (Kejadian 18: 20-21; lihat juga Yes 14: 3) Tuhan mengukur, membatasi, dan menilai integritas setiap kota. (Matius 11: 20-22; lihat juga Mat 11: 22-24; 23: 35-38). Tuhan menggunakan berbagai cara untuk berbicara dengan jelas ke setiap kota. (Mikha 6: 9; lihat juga Amsal 1:20, 21; 8: 1-7) Tuhan mempersiapkan, mengurapi, dan mengirimkan pelayanan tertentu ke kota-kota tertentu. (Yunus 1: 2; lihat juga Lukas 9: 51 56). Tuhan memiliki kunci utama untuk setiap kota. (2 Korintus 2:12; lihat juga Yoh 4; Kis 14:27). Tuhan menetapkan Gereja untuk berdiri di celah dan bersyafaat untuk kota. (Kel 32: 11-14; lihat juga Yehezkiel 9: 1-7; 22:30, 37). Tuhan berurusan dengan Gereja tentang bagaimana kaitannya dengan kota. Melalui rasul Yohanes, dia mengirim sebuah pesan ke gereja di kota Romawi 
di Philadelphia: (Wahyu 3: 7-8; lihat juga Wahyu 2-3). Tuhan memegang para tua-tua kota yang bertanggung jawab atas keadaan spiritualnya. (Ulangan 19: 11-12; lihat juga Daniel 21: 1-9; Yeh 3: 17-21; 33: 1-9) Tuhan menangisi nasib spiritual kota. (Lukas 19:41).

Keberadaan orang percaya dalam suatu tempat atau kota menentukan arah kota itu.

\section{Isteri serta Anak yang Laki laki dan Perempuan telah di Tawan.}

Istri dan anak adalah bagian dari keluarga. Keluarga adalah lembaga yang sangat penting di mata Tuhan. Apa yang penting bagi Tuhan menjadi penting bagi kita. Dialah yang membentuk keluarga untuk melanjutkan misiNya.

\section{Belajar dari sejarah}

Lima ratus tahun yang lalu, kebangunan rohani transformasional menyebar di seluruh Eropa. Seluruh bangsa dibentuk kembali oleh orang-orang percaya yang bergairah yang telah kembali ke kebenaran hanya dari Kitab Suci, hanya anugerah, hanya iman, hanya Kristus, dan semua untuk kemuliaan Allah. Gereja-gereja ditanam. Misionaris dikirim keluar. Dunia tidak pernah sama. Namun perhatikanlah keadaan spiritual Eropa saat ini.

Diperkirakan hanya $1-2 \%$ dari populasi dilahirkan kembali, orang-orang percaya di Eropa kehilangan jiwa anak-anak mereka ${ }^{14}$, generasi demi generasi. Jika kita tidak "membuat murid" dari penurunan rohani anak-anak dan cucu kita sendiri tidak terhindarkan.

Amerika sedang Jatuh, Gereja di Amerika mengikuti jalan tragis yang sama. Sejak tahun 1900, persentase orang Kristen yang percaya Alkitab telah menurun. Peneliti Thom Rainer ${ }^{15}$ menegaskan kenyataan yang memilukan. Di antara orang Amerika yang lahir sebelum tahun 1946, 65 persen

\footnotetext{
${ }^{14}$ Di simpulkan oleh penulis, ketika menghadiri NC2P (National Church Planting Process, di mana penulis hadir sebagai pengamat yang mewakili Asia pada tanggal 5-8 February 2018 15 Thom Rainer, The Book of Church Growth: History, Theology, and Principles. Nashville, TN: Broadman Press, 1993. p.349
} 
mengidentifikasi diri mereka sebagai orang Kristen dan mampu mengartikulasikan dasar-dasar Injil. Mereka yang lahir antara 1946 dan 1964, hanya 35 persen. Mereka yang lahir antara 1965 dan 1976, hanya 15 persen. Orang Amerika yang lahir antara 1974 dan 1994, hanya 4 persen dari populasi yang mengidentifikasi diri mereka sebagai orang Kristen dan telah mempercayai Kristus sendiri untuk keselamatan. Penginjilan dan pemuridan berada dalam krisis yang mengerikan, dan itu adalah krisis generasi. Kita kehilangan lebih banyak anak-anak kita sendiri ke dunia daripada kita memenangkan orang dewasa yang bertobat kepada iman di dalam Kristus.

Kekeristenan di Asia tidak jauh lebih baik, penurunan orang percaya di gereja gereja Korea, merupkan pelajaran yang harus di sikapi oleh gereja asia lainnya, termasuk Indonesia (bnd. Widjaja, F.I Misiologi Antara Teori, Fakta dan Pengalaman $)^{16}$

Bagaimana ini bisa terjadi? Ini adalah zaman gereja mega, megaprogramming, mega-anggaran, mega-konferensi, dan pelatihan kepemimpinan-mega. Acara penjangkauan, retret, dan perjalanan misi jangka pendek tidak pernah berakhir. Regenaris iman, iman yang tidak di turunkan kepada generasi berikutnya. Iman percaya yang hilang dalam ibadah ibadah keluarga?

Charles Spurgeon ${ }^{17}$ sangat prihatin dengan perubahan yang terjadi dalam budaya Kristen selama akhir abad ke-19. Dalam artikelnya, "Jenis Kebangunan yang Kita Butuhkan," dia menulis: Kami sangat menginginkan kebangkitan keluarga Kristen. Keluarga Kristen adalah benteng kesalehan di zaman orang-orang puritan, tetapi pada masa-masa kejam ini ratusan keluarga yang disebut Kristen tidak memiliki ibadat keluarga, tidak ada pengekangan atas anak-anak yang sedang tumbuh, dan tidak ada instruksi atau disiplin yang sehat. Bagaimana kita dapat berharap untuk melihat kerajaan Tuhan kita maju ketika murid-murid-Nya sendiri tidak mengajarkan Injil-Nya kepada anak-anak mereka sendiri?

\footnotetext{
${ }^{16}$ Fransiskus Irwan Widjaja, Misiologi Antara Teori, Fakta Dan Pengalaman, 1st ed. (Yogyakarta: Andi Offset, 2018).

17 Charles Spurgeon was deeply concerned about the changes which were occurring in Christian culture during the late 19th Century. In his article, "The Kind of Revival We Need"
} 


\section{Menuju Teologi Keluarga}

Apa hubungan alkitabiah antara Amanat Agung dan institusi keluarga? Allah telah menciptakan dua institusi penting untuk memajukan Kerajaan-Nya gereja lokal dan keluarga Kristen. Di dalam Alkitab, Allah memberikan kepada masing-masing lembaga peran, tanggung jawab, dan yurisdiksi yang unik. Perintah Pertama Allah membuat Adam dan Hawa dan Dia memberi mereka instruksi dalam

Kejadian 1:28:

Allah memberkati mereka, lalu Allah berfirman kepada mereka: "Beranakcuculah dan bertambah banyak; penuhilah bumi dan taklukkanlah itu, berkuasalah atas ikan-ikan di laut dan burung-burung di udara dan atas segala binatang yang merayap di bumi."

Sejak awal, Tuhan ingin mengisi Bumi, dengan orang-orang yang akan mengasihi-Nya, menyembah-Nya, dan membawa kemuliaan-Nya. Rencananya ini akan menjadi misi multi-generasi dan akan didukung oleh berkat pernikahan, memiliki anak, dan pemuridan keluarga generasi

Misi Tuhan untuk Abraham Dalam Kejadian 18:18, "Abraham menjadi bangsa yang besar dan kuat, dan semua bangsa di bumi akan diberkati melalui dia." Abraham menggenapkan keinginan Allah dalam Kejadian 12 dan 15, di mana rencana Allah untuk memberkati Abraham sehingga ia akan menjadi berkat bagi bangsa-bangsa. Rancangan Tuhan dilakukan Abraham sebagai tanggapan terhadap visi global dalam ayat 19 ,

Sebab Aku telah memilih dia, supaya diperintahkannya kepada anakanaknya dan kepada keturunannya supaya tetap hidup menurut jalan yang ditunjukkan TUHAN, dengan melakukan kebenaran dan keadilan, dan supaya TUHAN memenuhi kepada Abraham apa yang dijanjikanNya kepadanya

"Tuhan memilih Abraham, sehingga Abraham akan mengarahkan anakanaknya dan keluarganya untuk menjaga jalan Tuhan dengan melakukan apa yang benar dan adil, sehingga TUHAN akan mendatangkan bagi Abraham apa yang dia janjikan padanya. 
Perintah Agung Dalam Matius 22: 35-36 Yesus dihadapkan dengan pertanyaan yang kuat. Seorang pemimpin agama bertanya kepadanya, "Apa perintah yang paling penting dalam hukum?" Dia menjawab dengan mengutip dari Ulangan 6:5 
Kasihilah TUHAN, Allahmu, dengan segenap hatimu dan dengan segenap jiwamu dan dengan segenap kekuatanmu.

Menurut Yesus, tidak ada yang lebih penting daripada mengenal Allah dan mengasihi Dia.

\section{Ulangan 6: 6-7}

Apa yang kuperintahkan kepadamu pada hari ini haruslah engkau perhatikan, haruslah engkau mengajarkannya berulang-ulang kepada anak-anakmu dan membicarakannya apabila engkau duduk di rumahmu, apabila engkau sedang dalam perjalanan, apabila engkau berbaring dan apabila engkau bangun.

Tugas pertama untuk komunitas iman dalam menanggapi Perintah Agung; mengasihi Tuhan dengan memimpin anak-anak mereka untuk lebih mengasihi Dia. Inti dari Perintah Agung adalah pemuridan keluarga dan orang tua menjadi pelatih rohani utama bagi anak-anak. Tuhan memanggil orang tua untuk membawa keluarga bersama di rumah untuk apa yang orang Kristen turunkan melalui sejarah disebut "pemuridan keluarga." Pemuridan keluarga adalah waktu di mana keluarga berkumpul untuk berdoa, membaca Alkitab, dan dorongan rohani. Dia ingin setiap orang terlahir dakam keluarga bisa di muridkan.

Dalam Mazmur 78: 1-7

(1) Nyanyian pengajaran Asaf. Pasanglah telinga untuk pengajaranku, hai bangsaku, sendengkanlah telingamu kepada ucapan mulutku.

(2) Aku mau membuka mulut mengatakan amsal, aku mau mengucapkan teka-teki dari zaman purbakala.

3) Yang telah kami dengar dan kami ketahui, dan yang diceritakan kepada kami oleh nenek moyang kami,

(4) kami tidak hendak sembunyikan kepada anak-anak mereka, tetapi kami akan ceritakan kepada angkatan yang kemudian puji-pujian kepada TUHAN dan kekuatan-Nya dan perbuatan-perbuatan ajaib yang telah dilakukan-Nya.

(5) Telah ditetapkan-Nya peringatan di Yakub dan hukum Taurat diberiNya di Israel; nenek moyang kita diperintahkan-Nya untuk memperkenalkannya kepada anak-anak mereka,

(6) supaya dikenal oleh angkatan yang kemudian, supaya anak-anak, yang akan lahir kelak, bangun dan menceritakannya kepada anak-anak mereka,

(7) supaya mereka menaruh kepercayaan kepada Allah dan tidak melupakan perbuatan-perbuatan Allah, tetapi memegang perintah- 
Diberi gambaran tentang pengaruh keluarga yang kuat terhadap kemajuan Kerajaan Allah. Kebaikan Tuhan tidak akan di sembunyikannya dari anakanak memberi tahu generasi berikutnya tentang perbuatan yang dipuji Tuhan, kekuatannya, dan keajaiban yang telah Dia lakukan. Tuhan menetapkan undang-undang untuk Yakub dan menetapkan hukum di Israel, yang diperintahkan dari leluhur untuk mengajar anak-anak mereka, sehingga generasi berikutnya akan mengenal mereka, bahkan anak-anak yang belum dilahirkan, dan pada gilirannya akan memberi tahu anak-anak mereka. Maka mereka akan menaruh kepercayaan mereka pada Tuhan dan tidak akan melupakan perbuatannya tetapi akan menjaga perintahnya. "

Dalam Kisah Para Rasul 2, Petrus mengajarkan khotbah penginjilan yang luar biasa. Kisah Para Rasul 2: 38-39,

Jawab Petrus kepada mereka: "Bertobatlah dan hendaklah kamu masing-masing memberi dirimu dibaptis dalam nama Yesus Kristus untuk pengampunan dosamu, maka kamu akan menerima karunia Roh Kudus.

Sebab bagi kamulah janji itu dan bagi anak-anakmu dan bagi orang yang masih jauh, yaitu sebanyak yang akan dipanggil oleh Tuhan Allah kita."

Janji ini untuk yang merespon firman Tuhan dan anak-anak yang akan dipanggil oleh Tuhan Allah."

\section{Kesimpulan}

Bagiku tidak ada sukacita yang lebih besar dari pada mendengar, bahwa anak-anakku hidup dalam kebenaran I Yohanes 3:4

Pemuridan Keluarga adalah kehidupan rohani keluarga secara langsung terkait dengan Amanat Agung dan memenuhi bumi dengan para penyembah Kristus. Jika kita bersemangat melihat kemajuan Injil Kerajaan Kristus, mari kita mulai dengan membalikkan hati kita ke rumah. Mari kita meminta Tuhan untuk membantu kita memulai pelayanan kita di dunia ini dengan "membuat murid-murid" dari anggota keluarga kita. Marilah kita dengan penuh semangat 
dan alkitabiah membela rencana, struktur, dan tujuan Allah bagi institusi keluarga, serta institusi gereja lokal. Bagi kita dalam kepemimpinan gereja, marilah kita mengikuti teladan gereja mula-mula yang menjaga keluarga bersama untuk ibadah dan mempercepat penginjilan dan pemuridan di dalam dan melalui keluarga. Semoga Tuhan dimuliakan di gereja-gereja kita dan di rumah kita, serta kota kota boleh di pulihkan, sehingga Yesus dapat disembah di seluruh dunia di setiap suku dan bahasa untuk generasi yang akan datang. 
Daftar Pustaka

Atul Y. Aghamkar, 2000, Insights Into Openness,: Encouraging Urban Mission.

Beasly Murray 1962, Tour the Force seperti di kutip dalam buku Paul, Artemis, and the Jews in Ephesus, Volume 80

Charles Spurgeon In his article, "The Kind of Revival We Need" http://archive.spurgeon.org/revival.php di unduh 1 Agustus 2018

David C Cook, Bible Lesson Commentary 2013-2014, The Essential study for today disciple

Frank Damazio A Strategic Vision to Reach Cities and Nations, Regal Books 1999.

Fransiskus Irwan Widjaja, Misiologi Antara Teori, Fakta Dan Pengalaman, 1st ed. (Yogyakarta: Andi Offset, 2018).

Manokaran JN 2005 : Christ and Cities: Transformation of Urban Centres.

Paul G. Heibert. Cultural Anthropology. 1997

Robert C. Linthicum, 1991. Kota Allah Kota Setan.1991.

Thom Rainer, The Book of Church Growth: History, Theology, and Principles. Nashville, TN: Broadman Press, 1993.

Thompson Chain Referensi. Kirkbride Bible Company. Di unduh tgl 10-08-2 018

Von Harnack 1908, The Mission and Expansion of Christianity in The First Three Centuries, Vol 2.

William Webster Dictionary meaning of City, ttps://www.merriamwebster.com/dictionary/city di unduh, July 2015 